\title{
Demonstration of Two Protein Kinases in Extracts of Legionella micdadei
}

\author{
By ASISH K. SAHA, ${ }^{1}$ JOHN N. DOWLING, ${ }^{2 *}$ \\ NISHIT K. MUKHOPADHYAY ${ }^{1}$ AND ROBERT H. GLEW ${ }^{1}$ \\ Department of Microbiology, Biochemistry and Molecular Biology ${ }^{1}$ and Department of \\ Medicine ${ }^{2}$, University of Pittsburgh School of Medicine, Pittsburgh, PA 15261, USA
}

(Received 21 August 1987; revised 3 December 1987)

\begin{abstract}
Protein kinases I (PK I) and II (PK II) were purified 253- and 13·5-fold, respectively, from an extract of sonically disrupted cells of Legionella micdadei by ion-exchange chromatography on QAE-Sephadex, by histone affinity chromatography, and by HPLC-gel filtration chromatography. Both enzymes catalysed the phosphorylation of calf thymus histones, with a $K_{\mathrm{m}}$ of $2.7 \mathrm{mg} \mathrm{ml}^{-1}$ for PK I and $2.9 \mathrm{mg} \mathrm{ml}^{-1}$ for PK II. Histone $\mathrm{H}_{2 \mathrm{~b}}$ was the best protein kinase substrate for both PK I and PK II. The pH optima were 6.8 and 7.0 for PK I and PK II respectively. The $K_{\mathrm{m}}$ for ATP was $0.29 \mathrm{mM}$ for PK I and $0.33 \mathrm{~mm}$ for PK II. PK II activity was stimulated by either cAMP or cGMP, whereas PK I was inhibited by both cyclic nucleotides. The activity of PK I was unaffected by addition of calmodulin, diacylglycerol and mixtures of $\mathrm{Ca}^{2+}$ and acidic phospholipids, but these additions increased PK II activity threefold. The activity of PK II was stimulated by spermine and spermidine, but PK I was inhibited by these compounds. PK I and PK II were both strongly inhibited by heparin.
\end{abstract}

\section{INTRODUCTION}

Legionella pneumophila and Legionella micdadei cause bacterial pneumonia, but the mechanisms underlying their pathogenicity are largely unknown. The legionellae multiply in host mononuclear phagocytes (Horwitz \& Silverstein, 1980: Weinbaum et al., 1984) and are not killed efficiently by polymorphonuclear leucocytes (Horwitz \& Silverstein, 1981; Weinbaum et al., 1983). The properties of legionellae which promote their survival in the normally hostile environment within host phagocytic cells are beginning to be explored. In a previous study we found that $L$. micdadei contained an acid phosphatase which inhibited superoxide production by neutrophils following stimulation by the chemotactic peptide formyl-methionyl-leucylphenylalanine (Saha et al., 1985). Since protein phosphorylation plays an important role in the regulation of enzyme activity in many eukaryotic systems (Greengard, 1978; Rubin \& Rosen, 1975), this observation stimulated us to consider the possibility that phosphorylating enzymes in the legionellae might play a role in the pathophysiology caused by this family of organisms. In a preliminary experiment we detected substantial amounts of histone-specific protein kinase activity in extracts of $L$. micdadei.

Protein kinases of various types share the property of catalysing the phosphorylation of specific serine or threonine residues of protein substrates (Knowles, 1980). Evidence demonstrating the presence of multiple species of endogenous phosphorylated bacterial proteins and protein kinases in prokaryotes has been reported for Salmonella typhimurium (Wang \& Koshland, 1981) and Escherichia coli (Enami \& Ishihama, 1984; Manai \& Cozzone, 1982). In the case of E. coli, it has been demonstrated convincingly (Nimmo et al., 1984; Reeves \& Malloy, 1982) that NADP : isocitrate dehydrogenase undergoes phosphorylation and dephosphorylation; interestingly, both reactions are catalysed by a single bifunctional enzyme. In addition,

Abbreviations: PK I, protein kinase I; PK II, protein kinase II. 
Kuo \& Greengard (1969) partially purified an adenosine 3',5'-cyclic monophosphate (cAMP)dependent enzyme from $E$. coli that phosphorylated a non-bacterial protein, namely histone. It is unclear whether this enzyme is a protein kinase, or a polyphosphate kinase (Pastan \& Adhya, 1976).

Based upon data obtained with another intracellular parasite, Leishmania donovani (Das et al., 1986; Gottlieb \& Dwyer, 1981; Remaley et al., 1984, 1985), we considered the possibility that protein kinases and phosphatases on the legionella cell surface may play a role in pathogenesis. As a first step in investigating the possible pathophysiological significance of legionella protein kinases, we initiated a study of the enzyme activity in Legionella micdadei, an organism which has been the cause of mortality in immunocompromised patients (Pasculle et al., 1980).

\section{METHODS}

Materials. $\left[\gamma^{-32} \mathrm{P}\right]$ ATP $\left(5-10 \mathrm{Ci} \mathrm{mmol}^{-1} ; 185-370 \mathrm{GBq} \mathrm{mmol}^{-1}\right)$ was purchased from New England Nuclear, QAE-Sephadex from Pharmacia, and a Protein Pak $300 \mathrm{SW}$ column $(7.5 \times 600 \mathrm{~mm})$ from Waters Associates. Mixed histones from calf thymus, protamine, casein, phosvitin, calmodulin, cAMP, cGMP, phosphatidylserine, phosphatidylinositol, 1,2-dioleoyl-racemo-glycerol (diolein), spermine, spermidine, heparin, phenylmethylsulphonyl fluoride, aprotinin, leupeptin and protein kinase inhibitor from rabbit muscle were obtained from Sigma. Pure histone subtypes were a gift from Dr Sidney Morris, University of Pittsburgh, Pittsburgh, PA, USA. All other chemicals were of reagent grade and purchased from Fisher Scientific Co.

Bacteria. L. micdadei strain EK (ATCC 33204), which had been isolated originally in embryonated eggs from lung tissue of a patient with pneumonia (Pasculle et al., 1980), was used in all studies. Pooled yolk material from eggs was grown up on buffered charcoal yeast extract agar (Pasculle et al., 1980), containing 0.1\% (w/v) 2oxoglutarate and $1 \%(\mathrm{w} / \mathrm{v})$ bovine serum albumin (BCYE agar). Stock cultures, consisting of the growth from several BCYE agar plates suspended in nutrient broth containing $15 \%(\mathrm{v} / \mathrm{v})$ glycerol, were stored in portions at $-70^{\circ} \mathrm{C}$. Bacteria for the isolation of protein kinases were obtained by plating an appropriate dilution of the stock culture on BCYE agar plates. These cultures were incubated for $48-72 \mathrm{~h}$ at $35^{\circ} \mathrm{C}$ in ambient air until confluent growth was obtained.

Protein kinase assay. Protein kinase activity was assayed routinely with mixed histones serving as the phosphate acceptor in a $0.1 \mathrm{ml}$ assay composed of $50 \mathrm{~mm}$-Tris/HCl buffer ( $\mathrm{pH} 7 \cdot 0), 10 \mathrm{~mm}-\mathrm{MgCl}_{2}, 10 \mathrm{mM}-\mathrm{NaF}, 0.3 \mathrm{mg}$ mixed histones, $1 \mathrm{~mm}-\left[\gamma^{-32} \mathrm{P}\right] \mathrm{ATP}, 50 \mathrm{~mm}-\mathrm{NaCl}$ and $20 \mu \mathrm{l}$ of enzyme solution $(0 \cdot 05-1 \cdot 0 \mu \mathrm{g}$ protein). The reaction was initiated by addition of ATP and incubated at $37^{\circ} \mathrm{C}$. After $10 \mathrm{~min}, 1 \mathrm{ml}$ ice-cold $10 \%(\mathrm{w} / \mathrm{v})$ trichloroacetic acid (TCA) was added, followed by $20 \mu \mathrm{l}$ bovine serum albumin solution $\left(20 \mathrm{mg} \mathrm{ml}^{-1}\right)$. The pellet obtained by centrifugation $(5000 \mathrm{~g}, 10 \mathrm{~min})$ was dissolved in $0.2 \mathrm{ml}$ water and precipitated with $10 \%(\mathrm{w} / \mathrm{v}) \mathrm{TCA}$. After two more cycles of TCA precipitation, the precipitate was finally dissolved in $0.1 \mathrm{ml}$ water from which duplicate $40 \mu \mathrm{l}$ samples were taken and analysed for radioactivity as described by Corbin \& Reimann (1974). The control was prepared with boiled enzyme. One unit of activity was defined as the incorporation of 1 pmol ${ }^{32} \mathrm{P}$ into acidinsoluble product $\mathrm{min}^{-1}$. Substrate saturation kinetics were examined with varying concentrations of mixed histones (0.06-0.75 mM); slopes and intercepts were calculated according to the method of Cleland (1979).

Protein determination. Protein concentration was estimated by the method of Bradford (1976) with bovine serum albumin as standard.

Purification of protein kinases. All purification procedures were carried out at $4{ }^{\circ} \mathrm{C}$ unless otherwise indicated. The bacterial cells from 90-100 BCYE agar plates $(85 \mathrm{~mm}$ diam.) were suspended in $80-100 \mathrm{ml} 0.9 \% \mathrm{NaCl}$. We obtained $3.4 \mathrm{~g}$ (wet weight) of cells from 100 plates. The bacterial suspension was sonicated four times at 150 $200 \mathrm{~W}$ for $40 \mathrm{~s}$ (Braun-Sonic 2000, B. Braun Instruments). The sonication procedure was very efficient; resonication of the resuspended pellet released only $0.2 \%$ of protein kinase activity present in the original crude homogenate. Debris from the sonicated cell suspension was removed by centrifugation at $37000 \mathrm{~g}$ for $30 \mathrm{~min}$, after which the extract was centrifuged at $100000 \mathrm{~g}$ for $60 \mathrm{~min}$.

$Q A E$-Sephadex chromatography. The resulting supernatant fraction was applied to a QAE-Sephadex A-50 column $(15 \times 80 \mathrm{~mm})$ that was equilibrated with $10 \mathrm{~mm}$-sodium citrate buffer, pH 6.5, supplemented with $10 \mathrm{mM}$ 2-mercaptoethanol (designated 'standard citrate buffer') and $50 \mathrm{~mm}$ each of leupeptin, aprotinin and phenylmethylsulphonyl fluoride, at a flow rate of $0.2 \mathrm{ml} \mathrm{min}^{-1}$. Fractions of $2 \mathrm{ml}$ were collected and analysed for protein (absorbance at $280 \mathrm{~nm}$ ) and protein kinase activity. Approximately $72 \%$ of the protein kinase activity appeared in the column breakthrough fractions; this fraction was designated as PK I. The column was then developed with $100 \mathrm{ml}$ of a linear $0-0.5 \mathrm{M}$-sodium chloride gradient in standard citrate buffer. The conductivity of each fraction was determined using a Radiometer conductivity meter (type CDM 2F). A single peak of protein kinase activity was eluted with approximately $0 \cdot 25$ M-sodium chloride and designated at PK II. The PK I and PK II activity fractions were pooled, and the two pools were dialysed separately against two changes of standard citrate buffer containing $50 \%(\mathrm{v} / \mathrm{v})$ glycerol. 
Histone affinity chromatography. After dialysis, as described above, fractions containing PK I and PK II activity were applied separately to a histone affinity column $(15 \times 70 \mathrm{~mm})$ prepared by covalently attaching calf thymus histones to Sepharose 4B as described by Wilchek et al. (1984). The column buffer was standard citrate buffer. After loading each sample, the column was washed with $50 \mathrm{ml}$ column buffer, followed by $50 \mathrm{ml}$ column buffer containing $0.5 \mathrm{M}$-sodium chloride to elute protein kinase activity; $2 \mathrm{ml}$ fractions were collected. The histone affinity column can be used at least three times.

HPLC gel filtration chromatography. The pooled fractions from the histone affinity column were dialysed against $10 \mathrm{~mm}$-sodium phosphate buffer, $\mathrm{pH} 6.5$, containing $10 \mathrm{~mm}-2$-mercaptoethanol and $50 \%(\mathrm{v} / \mathrm{v})$ glycerol and applied to an HPLC gel filtration column (Waters Protein Pak $300 \mathrm{SW}, 7.5 \times 600 \mathrm{~mm}$ ). The fractionation range of this column is approximately $40000-150000$. The column was fitted to a Waters Associates M-45 solvent delivery system and the eluate was passed through a Waters absorbance detector (model 440) coupled to a GoerzMetrawatt recorder (model SE 120). The column was equilibrated in 10 mm-sodium phosphate buffer, $\mathrm{pH} 6.5$, containing $10 \mathrm{~mm}-2$-mercaptoethanol and developed at a flow rate of $0.5 \mathrm{ml} \mathrm{min}^{-1}$. Fractions of $1 \mathrm{ml}$ were collected and analysed for protein kinase activity. Fractions constituting the single peak of protein kinase activity were pooled and dialysed against standard citrate buffer containing $50 \%(\mathrm{v} / \mathrm{v})$ glycerol. The kinase preparations lost less than $10 \%$ of their activity when stored for $15 \mathrm{~d}$ at $0-4{ }^{\circ} \mathrm{C}$ in standard citrate buffer containing $50 \%(\mathrm{v} / \mathrm{v})$ glycerol.

\section{RESULTS}

\section{Purification of protein kinases}

The crude sonicate of $L$. micdadei contained a substantial amount of protein kinase activity (Table 1). The resolution and partial purifications of the two L. micdadei protein kinases were monitored with mixed histones serving as the exogenous phosphate acceptor in the kinase assay. The $100000 \mathrm{~g}$ supernatant fraction of the crude bacterial extract contained more than $85 \%$ of the total protein kinase activity. When this material was chromatographed on a QAE-Sephadex column (Fig. 1), about $72 \%$ of the protein kinase activity appeared in the breakthrough fractions (PK I) while the remainder (PK II) was eluted by the salt gradient.

The results of the purification schemes for PK I and PK II are summarized in Table 1. Relative to the crude homogenate, PK I was purified 253-fold. However, PK II was purified only 13.5-fold. The specific activities of the final preparations of PK I and PK II were $1.01 \times 10^{5}$ and $1.33 \times 10^{3} \mathrm{U}$ (mg protein $)^{-1}$, respectively, when assayed using mixed histones as the phosphate acceptor. The overall activity yield of these two protein kinases was $38 \%$ (Table 1 ). The purification procedure was performed three times and was very reproducible. The data summarized in Table 1 are representative of these three experiments.

Proof that the ${ }^{32} \mathrm{P}$-labelled product generated by PK I was, in fact, ${ }^{32} \mathrm{P}$-histone and not polyphosphate (Pastan \& Adhya, 1976; Li \& Brown, 1973) was obtained by subjecting the incubation medium to SDS-PAGE and chromatography on a Sephadex G-100 column; the radioactive product coelectrophoresed and cochromatographed precisely with histone standard (data not shown).

\section{Substrate specificity}

A variety of potential phosphate acceptors were compared in the standard kinase assay (Table 2), namely, mixed histones, protamine, casein and phosvitin. In the case of PK I, only the mixed histones and protamine supported significant activity. Mixed histones were the preferred substrate for PK II. Little incorporation of $\left[\gamma^{-32}\right.$ P $]$ ATP into TCA-precipitable material was obtained when histone was omitted from the kinase assay. The histone subfractions were not equally effective acceptors for PK I or PK II ; in each case, histone subtype $\mathrm{H}_{2 b}$ was the best acceptor and $\mathrm{H}_{1}$ the poorest.

The $K_{\mathrm{m}}$ values with mixed histones as the substrate for PK I $\left(2 \cdot 7 \mathrm{mg} \mathrm{ml}^{-1}\right)$ and PK II $\left(2.9 \mathrm{mg} \mathrm{ml}^{-1}\right)$ were indistinguishable. Above $8 \mathrm{mg} \mathrm{ml}^{-1}$ the mixed histones inhibited the activities of both kinases by $30 \%$. The effect of ATP concentration on kinase activity was examined in the range 0.05-3.0 mM-ATP. From the Lineweaver-Burk plots of the data, $K_{\mathrm{m}}$ values of 0.29 and $0.33 \mathrm{~mm}$-ATP were estimated for PK I and PK II, respectively. 


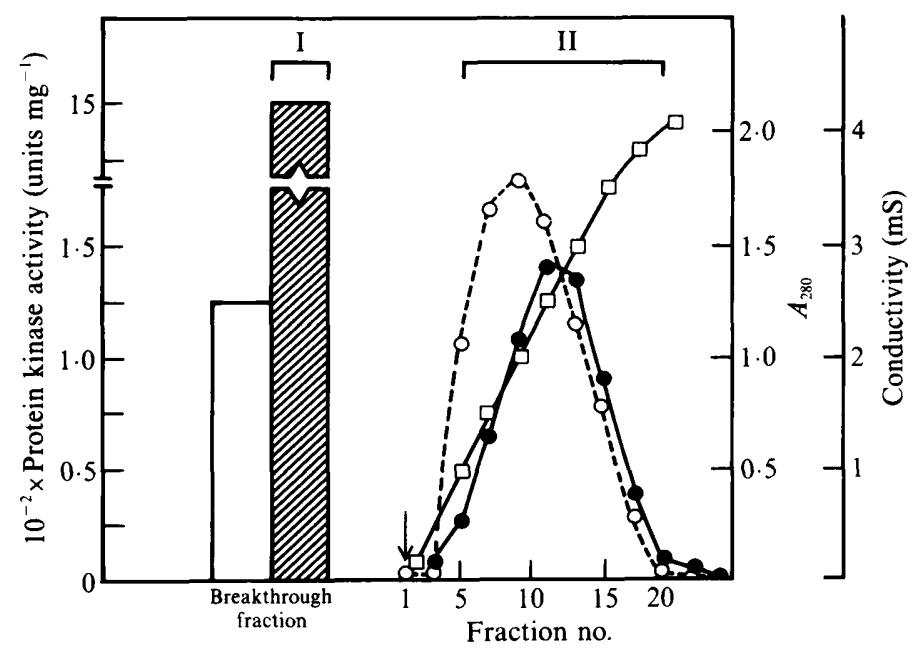

Fig. 1. QAE-Sephadex chromatography of $L$. micdadei protein kinase. The protein kinase activity from high-speed supernatant was further purified by chromatography on a $15 \times 80 \mathrm{~mm}$ column containing QAE-Sephadex A-50 equilibrated in 0.01 M-citrate buffer, pH 6.5. The column was washed with 5 bed volumes of the same buffer (total volume of breakthrough, $30 \mathrm{ml}$ ) followed by elution (flow rate, $0 \cdot 2 \mathrm{ml}$ $\left.\mathrm{min}^{-1}\right)$ with a $100 \mathrm{ml}$ linear $\mathrm{NaCl}$ gradient $(0.0-0.5 \mathrm{M}-\mathrm{NaCl}$ in standard citrate buffer, $\mathrm{pH} 6.5)$ initiated where indicated by the arrow. Fractions $(2 \mathrm{ml})$ were collected and analysed for $A_{280}(O)$, protein kinase activity (O) and conductivity ( $\square$ ). The open bar represents $A_{280}$, and the hatched bar the protein kinase activity, of the breakthrough fraction. Pools I and II were designated PK I and PK II, respectively. The data are representative of three experiments.

Table 1. Summary of purification of protein kinases I and II from L. micdadei

The data are representative of three experiments.

Purification step

1. Crude homogenate

2. $100000 g$ supernatant fraction

3. QAE-Sephadex

PK I

PK II

4. Histone affinity

PK I

PK II

5. HPLC

PK I

PK II

$$
\begin{gathered}
10^{-2} \times \text { Total } \\
\text { activity } \\
\text { (units) }^{*}
\end{gathered}
$$

266
231
166
52

146
47
81
20

$\begin{gathered}\text { Total } \\ \text { protein } \\ (\mathrm{mg})\end{gathered}$
65.0
59.0
11.5
30
1.7
7.0

0.08
1.5

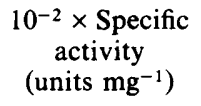

* One unit of kinase activity equals $1 \mathrm{pmol}^{32} \mathrm{P}$ incorporated $\min ^{-1}$ measured using mixed histones as substrate. † Calculated by adding the activities of the two protein kinases.

$\ddagger$ Calculated relative to the crude homogenate and assuming that $[52 /(52+166)] \times 100$ represents the percentage of PK II in the crude homogenate.

\section{Metal ion requirement}

The activity of PK II was strongly dependent on the inclusion of $\mathrm{NaCl}(50 \mathrm{~mm}), \mathrm{MgCl}_{2}$ $(10 \mathrm{mM})$ and $\mathrm{NaF}(10 \mathrm{~mm})$ in the assay. $\mathrm{CaCl}_{2}(1.0 \mathrm{mM})$ stimulated PK II activity threefold. Omission of $\mathrm{NaCl}$ and $\mathrm{NaF}$ reduced PK I activity by $30 \%$ and $15 \%$, respectively. Neither exogenous $\mathrm{Mg}^{2+}$ nor $\mathrm{Ca}^{2+}$ was required for PK I activity. In the absence of $\mathrm{Ca}^{2+}$, both kinases were inhibited about $40 \%$ by $1.0 \mathrm{mM}-\mathrm{MnCl}_{2}$ (data not shown). 
Table 2. Substrate specificity of PKI and PKII

The protein kinase assay was carried out with the specified amount of substrate in a $0 \cdot 1 \mathrm{ml}$ assay mixture for $10 \mathrm{~min}$ at $37^{\circ} \mathrm{C}$ and was terminated by TCA precipitation (see Methods). One unit of kinase activity equals $1 \mathrm{pmol}{ }^{32} \mathrm{P}$ incorporated $\mathrm{min}^{-1}$. The data were derived from duplicate analysis of a single experiment. The numbers in parenthesis represent one standard error of the mean.

\begin{tabular}{|c|c|c|c|}
\hline \multirow[b]{2}{*}{ Substrate } & \multirow{2}{*}{$\begin{array}{c}\text { Amount of substrate } \\
\text { per incubation } \\
(\mu \mathrm{g})\end{array}$} & \multicolumn{2}{|c|}{$\begin{array}{c}10^{-2} \times \text { Protein kinase activity } \\
\quad\left(\text { units } \mathrm{ml}^{-1}\right)\end{array}$} \\
\hline & & PK I & PK II \\
\hline None & - & $3.2 \quad(0 \cdot 6)$ & $0.50(0.25$ \\
\hline Mixed histones & 300 & $33.7 \quad(1.0)$ & $11.5 \quad(1.3)$ \\
\hline & 100 & $12.6 \quad(0.8)$ & $5.35(0.45$ \\
\hline Histone subtype & & & \\
\hline $\mathrm{H}_{1}$ & 100 & $0.21(0.08)$ & $0.04(0.02$ \\
\hline $\mathbf{H}_{3}$ & 100 & $1.84(0.30)$ & $0.62(0.25$ \\
\hline $\mathbf{H}_{2 \mathrm{~b}}$ & 100 & $4.85(0.80)$ & $1.66(0.20$ \\
\hline $\mathrm{H}_{2 \mathrm{a}}$ & 100 & $4.19(0.75)$ & $1.06(0.25$ \\
\hline $\mathrm{H}_{4}$ & 100 & $2.54(0.50)$ & $1.52(0.30$ \\
\hline Protamine & 300 & $12.1 \quad(0.75)$ & $1.4(0 \cdot 10$ \\
\hline Casein & 300 & $2.4 \quad(0.40)$ & $1.0 \quad(0.25$ \\
\hline Phosvitin & 200 & $1.7 \quad(0.30)$ & $0.90(0.15$ \\
\hline
\end{tabular}

Table 3. Effect of various additions on the activities of PK I and PK II

The phosphorylation reaction was carried out for $10 \mathrm{~min}$ at $37^{\circ} \mathrm{C}$ as described in Methods, with $20 \mu \mathrm{l}$ of partially purified protein kinase. The 'control' contained all the components of the standard reaction mixture. One unit of protein kinase activity is equal to $1 \mathrm{pmol}^{32} \mathrm{P}$ incorporated $\mathrm{min}^{-1}$. The data are representative of two experiments performed in duplicate. The numbers in parenthesis represent one standard error of the mean.

Addition(s) to the assay medium

None

$0.1 \mathrm{mM}-\mathrm{cAMP}$

10 mM-cAMP

$0 \cdot 1 \mathrm{mM}-\mathrm{cGMP}$

$10 \mathrm{mM}$-cGMP

$3.5 \mu \mathrm{g}$ calmodulin

$10 \mu \mathrm{M}-\mathrm{Ca}^{2+}$ and $3.5 \mu \mathrm{g}$ calmodulin

$10 \mu \mathrm{M}-\mathrm{Ca}^{2+}$ and $10 \mu \mathrm{g}$ phosphatidylserine

$10 \mu \mathrm{M}-\mathrm{Ca}^{2+}$ and $10 \mu \mathrm{g}$ phosphatidylinositol

$15 \mu \mathrm{M}$-diolein

$10 \mu \mathrm{M}-\mathrm{Ca}^{2+}, 10 \mu \mathrm{g}$ phosphatidylinositol and $15 \mu \mathrm{M}$-diolein

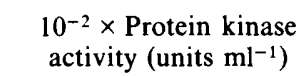

$\begin{array}{cc}\text { PK I } & \text { PK II } \\ 26.1(2.0) & 13.6(1.8) \\ 21.2(1.3) & 16.0(0.8) \\ 15.7(1.0) & 26.1(2.0) \\ 16.0(0.5) & 17.0(2.5) \\ 15.5(1.2) & 19.0(2 \cdot 1) \\ 20 \cdot 1(1.5) & 21.5(2.0) \\ 29.2(1.2) & 40.2(2.5) \\ 27.5(2.0) & 38.5(0.8) \\ 29.6(0.5) & 42.3(2.6) \\ 28.1(1.0) & 39.5(1.2) \\ 25.6(1.5) & 51.2(3.2)\end{array}$

\section{Effects of $\mathrm{pH}$ on protein kinase activity}

Both protein kinases exhibited maximum activity at pH 6.8-7.0. However, the pH-activity profile of PK I was much sharper than that of PK II (data not shown).

\section{Effects of cyclic nucleotides and other agents on enzyme activity}

The activity of PK I was inhibited by $20 \%$ and $40 \%$ by $0.1 \mathrm{mM}^{-}$and $10 \mathrm{mM}-\mathrm{cAMP}$, respectively, and $40 \%$ by $0 \cdot 1$ or $10 \mathrm{mM}-\mathrm{cGMP}$. The activity of PK II was stimulated by $15 \%$ and $48 \%$ by $0.1 \mathrm{mM}$ - and $10 \mathrm{mM}$-cAMP, respectively, and by $25 \%$ and $40 \%$ by 0.1 and $10 \mathrm{mM}-\mathrm{cGMP}$, respectively (Table 3 ).

That PK I was not cyclic-nucleotide-dependent was supported by the observation that the protein kinase inhibitor from rabbit muscle $\left(0.5 \mathrm{mg} \mathrm{m}^{-1}\right)$ had little or no effect on this kinase (data not shown). In contrast, the inclusion of this inhibitor $\left(0.5 \mathrm{mg} \mathrm{m}^{-1}\right)$ in the assay for PK II reduced kinase activity by more than $50 \%$, both in the presence and absence of cAMP $(0 \cdot 1 \mathrm{mM})$. 
This last observation reinforced the conclusion that PK II was cAMP-dependent. Calmodulin by itself inhibited PK I activity by about $25 \%$ and stimulated PK II activity 1.5 -fold. However, the $\mathrm{Ca}^{2+} /$ calmodulin mixture stimulated PK I activity by only $10 \%$, whereas PK II activity was increased nearly threefold.

PK I activity was unaffected by a mixture of $\mathrm{Ca}^{2+}(10 \mu \mathrm{M})$ and phosphatidylserine $(10 \mu \mathrm{g}$ per assay) and stimulated only $13 \%$ by a mixture of $\mathrm{Ca}^{2+}$ and phosphatidylinositol (10 $\mu \mathrm{g}$ per assay), while these substances stimulated PK II activity threefold. Diolein $(10 \mu \mathrm{M})$ stimulated PK I activity by only $7 \%$ and the $\mathrm{Ca}^{2+} /$ phosphatidylinositol/diolein mixture had no effect. However, both additions stimulated PK II activity three- to fourfold (Table 3).

Since some protein kinases are affected by polyamines (Glover et al., 1983; Tabor \& Tabor, 1976) and heparin (Hathaway et al., 1980; Yutani et al., 1982), the effects of these compounds were examined using mixed histones as the phosphate acceptor. PK II activity was stimulated about 1.5 -fold by $0.5 \mathrm{~mm}$-spermine or spermidine, and threefold when the concentration of either of these polyamines in the assay medium was $2 \mathrm{mM}$. In contrast, a $0.5 \mathrm{~mm}$ concentration of either of these polyamines inhibited PK I activity about $50 \%$. Both kinases were inhibited by heparin, but their heparin sensitivity differed: $0.4 \mathrm{mg}$ heparin $\mathrm{ml}^{-1}$ inhibited PK I activity completely but only inhibited PK II activity by about $50 \%$ (data not shown).

\section{DISCUSSION}

In this study, two protein kinase activities, PK I and PK II, were resolved and partially purified from an extract of Legionella micdadei. As pointed out by Li \& Brown (1973), bacterial protein kinases that appear to phosphorylate non-bacterial proteins must be differentiated from polyphosphate kinase activity. E. coli contains a polyphosphate kinase which incorporates [ $\gamma^{-32}$ P]ATP into TCA-precipitable material, this reaction being stimulated by histone or protamine (Li \& Brown, 1973). However, the stimulation by histone occurs only in phosphate buffer, and in the absence of phosphate ions, histone is inhibitory; the polyphosphate kinase activity is also inhibited by $\mathrm{NaCl}$ and $\mathrm{NaF}$ (Li \& Brown, 1973). Since our protein kinase assays were performed in the presence of $\mathrm{NaF}$ and $\mathrm{NaCl}$ and in the absence of phosphate, it is unlikely that polyphosphate kinase activity would be reflected in our assay. More definitive evidence that our assay for PK I and PK II was not detecting polyphosphate kinase activity was our finding that when the radiolabelled products of the kinase assay were subjected to SDS-PAGE and Sephadex G-100 chromatography, all of the radioactivity coincided precisely with the histone peaks (data not shown).

L. micdadei PK I is cyclic-nucleotide-independent, whereas PK II is cAMP- and cGMPdependent. In this respect, PK I is similar to certain protein kinases in other pathogens including Leishmania donovani (Das et al., 1986), Plasmodium berghei and Plasmodium chabudi (Wiser et al., 1983). These organisms also contain protein kinases that are cAMP-independent and which phosphorylate serine residues of certain proteins.

Polyamines affect the activity of several protein kinases (Glover et al., 1983; Tabor \& Tabor, 1976). Like a protein kinase of Candida albicans, Legionella micdadei PK I was markedly inhibited by the polyamines spermine and spermidine (Gupta Roy \& Datta, 1986).

We have not yet determined the subcellular location of the protein kinases of L. micdadei. Nevertheless, it is possible that these enzymes may play some role in disarming host cells by interfering with antimicrobial processes. For example, it has been shown that phosphorylation of tubulin, the principal protein of microtubules, inhibits the ability of this cytoskeletal protein to bind to microtubule-associated proteins or to polymerize (Wandosell et al., 1986). It remains to be seen if host cell proteins such as tubulin are phosphorylated by the $L$. micdadei protein kinases. Further studies are needed to elucidate the role of these bacterial protein kinases and to identify endogenous (bacterial) or exogenous (host cellular) substrates that might function as phosphate acceptors for these enzymes.

The authors thank Philip Lauro and James Kelton for technical assistance, and Teresa Poloka, Linda Whigham and Betty Edwards for secretarial assistance.

This work was supported by Public Health Service grants AI-1 7047 and AI-18945 from the National Institute of Allergy and Infectious Diseases. 


\section{REFERENCES}

BRADFORD, M. M. (1976). A rapid and sensitive method for the quantitation of microgram quantities of protein utilizing the principle of protein dye binding. Analytical Biochemistry 72, 248-256.

Cleland, W. W. (1979). Statistical analysis of enzyme kinetic data. Methods in Enzymology 63, 103-138.

Corbin, J. D. \& Reimann, E. M. (1974). Assay of cyclic AMP-dependent protein kinases. Methods in Enzymology 38, 287-290.

Das, S., Saha, A. K., Mukhopadhyay, N. K. \& Glew, R. H. (1986). A cyclic nucleotide-independent protein kinase in Leishmania donovani. Biochemical Journal 240, 641-649.

Enami, M. \& Ishinama, A. (1984). Protein phosphorylation in Escherichia coli and purification of a protein kinase. Journal of Biological Chemistry 259, 526-533.

Glover, C. V. C., Shelton, E. R. \& Brutlag, D. L. (1983). Purification and characterization of a type II casein kinase from Drosophila melanogaster. Journal of Biological Chemistry 258, 3258-3265.

Gottlieb, M. \& DWyer, D. (1981). Protozoan parasite of human: surface membrane with externally disposed acid phosphatase. Science 212, 939-941.

GreEnGard, P. (1978). Phosphorylated proteins and physiological effectors. Science 199, 146-152.

GuPTA RoY, B. \& DatTA, A. (1986). A cyclic AMPindependent protein kinase from Candida albicans. Biochemical Journal 234, 543-546.

Hathaway, G. M., Lubben, T. H. \& Traugh, J. A (1980). Inhibition of casein kinase II by heparin. Journal of Biological Chemistry 255, 8038-8041.

Horwitz, M. A. \& Silverstein, S. C. (1980). Legionnaire's disease bacterium (Legionella pneumophila) multiplies intracellularly in human monocytes. Journal of Clinical Investigation 66, 441-450.

Horwitz, M. A. \& Silverstein, S. C. (1981). Interaction of the Legionnaire's disease bacterium (Legionella pneumophila) with human phagocytes. I. L. pneumophila resists killing by polymorphonuclear leukocytes, antibody, and complement. Journal of Experimental Medicine 153, 386-397.

KNOWLES, J. R. (1980). Enzyme-catalyzed phosphoryl transfer reactions. Annual Review of Biochemistry 49 , 877-919.

Kuo, J. F. \& GreEngard, P. (1969). An adenosine 3',5'-monophosphate-dependent protein kinase from Escherichia coli. Journal of Biological Chemistry 244, 3417-3419.

LI, H. C. \& Brown, G. G. (1973). Orthophosphate and histone dependent polyphosphate kinase from $E$. coli. Biochemical and Biophysical Research Communications 53, 875-881.

ManaI, M. \& Cozzone, J. (1982). Endogenous protein phosphorylation in Escherichia coli extracts. Biochemical and Biophysical Research Communications 107, 981-988.

Nimmo, G. A., Borthwick, A. C., Holms, W. H. \& Nimmo, H. G. (1984). Partial purification and properties of isocitrate dehydrogenase kinase/phosphatase from Escherichia coli ML 308. European Journal of Biochemistry 141, 401-408.

Pasculle, A. W., Feeley, J. C., Gibson, R. J.,
Cordes, L. G., Myerowitz, R. L., Patton, C. M., Gorman, G. W., Carmack, C. L., Ezzell, J. W. \& Dowling, J. N. (1980). Pittsburgh pneumonia agent: direct isolation from human lung tissue. Journal of Infectious Diseases 141, 727-731.

Pastan, I. \& Adhya, S. (1976). Cyclic adenosine 5'monophosphate in Escherichia coli. Bacteriological Reviews 40, 527-551.

Reeves, H. C. \& Malloy, P. J. (1982). The phosphorylation of isocitrate dehydrogenase in Escherichia coli. Biochemical Society Transactions 10; 321-322.

Remaley, A. T., Kuhns, D. B., Basford, R. E., Glew, R. H. \& KaPLAN, S. S. (1984). Leishmanial phosphatase blocks neutrophil $\mathrm{O}_{2}^{-}$production. Journal of Biological Chemistry 259, 11173-11175.

Remaley, A. T., Das, S., Campbell, P. I., Larocca, G. M., POPE, M. T. \& Glew, R. H. (1985). Characterization of Leishmania donovani acid phosphatase. Journal of Biological Chemistry 260, 880886.

Rubin, C. S. \& Rosen, O. M. (1975). Protein phosphorylation. Annual Review of Biochemistry 44, 831-887.

Saha, A. K., Dowling, J. N., Lamarco, K. L., Das, S., Remaley, A. T., Olomu, N., Pope, M. T. \& Glew, R. H. (1985). Properties of an acid phosphatase from Legionella micdadei which blocks superoxide anion production by human neutrophils. Archives of Biochemistry and Biophysics 243, 150-160.

TABOR, C. W. \& TABOR, H. (1976). 1,4-Diaminobutane (putrescine), spermidine and spermine. Annual Review of Biochemistry 45, 285-306.

Wandosell, F., Serrano, L., Hernandez, M. A. \& Avila, J. (1986). Phosphorylation of tubulin by a calmodulin-dependent protein kinase. Journal of Biological Chemistry 261, 10332-10339.

WanG, J. Y. J. \& Koshland, D. E., JR (1981). The identification of distinct protein kinases and phosphatases in the prokaryote Salmonella typhimurium. Journal of Biological Chemistry 256, 4640-4648.

Weinbaum, D. L., Bailey, J., Benner, R. R., Pasculle, A. W. \& Dowling, J. N. (1983). The contribution of human neutrophils and serum to host defense against Legionella micdadei. Journal of Infectious Diseases 148, 510-517.

Weinbaum, D. L., Benner, R. R., Dowling, J. N., Alpern, A., Pasculle, A. W. \& Donowitz, G. R. (1984). Interaction of Legionella micdadei with human monocytes. Infection and Immunity 46, 68-73.

WilcheK, M., Miron, T. \& KoHN, J. (1984). Affinity chromatography. Methods in Enzymology 104, 3-55.

WISER, M. F., EATON, J. W. \& Sheppard, J. R. (1983). A plasmodium protein kinase that is developmentally regulated, stimulated by spermine, and inhibited by quercetin. In Molecular Biology of the HostParasite Interactions, pp. 7-16. Edited by N. Agabian \& H. Eiser. New York: Alan R. Liss.

Yutani, Y., Tei, Y., Yukioka, M. \& INONE, A. (1982). Occurrence of NI and NII type protein kinases in the nuclei from various tissues of the rat. Archives of Biochemistry and Biophysics 218, 409-420. 